\title{
Las bodas de la realeza y sus celebraciones festivas en España y América durante el siglo XVIII
}

\author{
David González Cruz*
}

\begin{abstract}
RESUMEN ABSTRACT
El presente trabajo estudia las ceremonias y fiestas organizadas en España y América con motivo de las bodas de miembros de la Familia Real.

Esta linea central de la investigación inserta, además, otros aspectos y cuestiones que se desprenden del análisis: protagonismo de la politica exterior en los enlaces nupciales. imagen de la monarquia española, organizadores y participantes en los festejos, papel desempeñado por las elites políticas y sociales, diseño de la propaganda pedagógica dirigida a los hispanoamericanos, $y$ festejos programados para fomentar el culto a la Corona y atraer la atención de los súbditos (bailes, banquetes, recepciones y comitivas reales, fiestas de toros, torneos, juegos de cañas $y$ sortijas, misas de acción de gracias, paseos y carros triunfales, fiestas de moros y cristianos, teatro y desfiles de máscaras).

The article deals with ceremonies and festivals organized in Spain and Spanish America in the occasion of royal weddings. This central topic permits to reveal other aspects: priority of foreign policy in these weddings, image of Spanish Monarchy, organizers and participants, role played by politic and social elites, design of pedagogic propaganda towards American subjects, festivals intended to promote the cult of the Crown and to attract the general attention (balls, banquets, royal receptions and retinues, bullfights, jousts, canes and rings, thanksgiving masses, walks, floats, moros y cristianos festivals, dramatic plays ans mask parades).

\footnotetext{
* Área de Historia Moderna. Universidad de Huelva.
} 


\section{FUENTES Y CONSIDERACIONES GENERALES}

Este texto supone un primer avance del proyecto de investigación que actualmente estoy llevando a cabo sobre la imagen de España y de su Monarquía en América durante la época colonial. Sin duda, en el mencionado proyecto las fiestas -especialmente las ceremonias públicas relacionadas con la realeza- deben ser un tema de obligada atención en cuanto que manifestaron la presencia de la Corona en todos los territorios del Imperio Español.

Es en este contexto en el que los festejos organizados con motivo de la celebración del algún acontecimiento vinculado a la Familia Real (nacimientos, matrimonios, onomásticas, cumpleaños, exequias fúnebres, proclamaciones reales, juras de herederos, etc.) representaron una oportunidad, habitualmente aprovechada por las diferentes instituciones del Estado, para trasladar a los súbditos un mensaje propagandístico sobre las virtudes de la Corona y de su sistema político. Al mismo tiempo, esas celebraciones recogían la imagen que tenía de la Monarquía el conjunto de la sociedad hispanoamericana; no obstante, la documentación normalmente nos acerca, con cierta exclusividad, a una expresión ritualizada de los vínculos existentes entre el Soberano y el pueblo, que quedan reflejados en unos hábitos de conducta estereotipados y repetidos en todos los lugares, villas y ciudades de España y América, y que no siempre permiten penetrar en la esencia última de esa relación del rey con sus súbditos.

En esta ocasión, lejos de hacer un análisis de la totalidad de los eventos a los que me he referido con anterioridad, me voy a circunscribir a las ceremonias y fiestas públicas programadas con motivo del casamiento de algún miembro de la Familia Real Española. Precisamente, la celebración de un matrimonio de la realeza resultaba ser el acontecimiento de este tipo - frente a otros que se han mencionado- que mejor proyectaba de forma unificada la imagen interna que tuvo la Monarquía en sus reinos y, al mismo tiempo, el prestigio exterior alcanzado entre las distintas dinastías y potencias europeas.

Realmente, los actos y festejos organizados con motivo de las bodas reales pueden ser abordados desde un conjunto extenso de fuentes; no en vano, la magnificencia y suntuosidad que desprendían originaba que la sociedad se insertase de lleno en las celebraciones y que se hiciese eco de ellas en una variada tipología documental: correspondencia, actas de cabildos, legislación, publicidad oficial, prensa periódica, pleitos judiciales, libros, manuscritos, panegíricos de las academias, etc. Siendo consciente de esta evidencia, una vez que el proyecto de investigación al que me he 
referido concluya habrá sido posible consultar cada una de estas fuentes; en este sentido, sin renunciar al afán globalizador que debe caracterizar a toda investigación, pero teniendo en cuenta que este artículo trata de ser un primer avance del estudio que actualmente estoy realizando, lo que se pretende con él es reflejar principalmente la visión que ofrece la prensa periódica americana en relación con las bodas de los miembros de la Familia Real y de los actos organizados para ensalzar dichos eventos. Sin duda, la preferencia por el análisis de las narraciones dedicadas a los matrimonios de la realeza que eran publicadas en los periódicos americanos del siglo XVill radica en que, a diferencia de la prensa europea, poseían una doble virtualidad: por un lado, reproducian las ceremonias matrimoniales y actos que tenían lugar en España o en el país de origen del cónyuge $y$, por otro, al mismo tiempo informaban de los ecos que llegaban a las colonias americanas y de los festejos que en estas tierras del otro lado del Atlántico exaltaban los acontecimientos favorables a la Monarquía Española.

Sin discusión, las citadas narraciones - ya fuesen las editadas en los periódicos o las recogidas en libros impresos- obtuvieron una gran difusión, tanto en España como en América. A este respecto, no debe extranar que estuviese muy extendida la afición de leer las noticias dedicadas a los espectáculos -especialmente los referidos a la Corte Española o, en su caso, a las diferentes cortes virreinales-; de ahi que fuese habitual que las personas interesadas en conocer tales acontecimientos trasladaran al papel copias manuscritas de las diferentes gacetas y diarios que relataban estos eventos ' . Este efecto multiplicador que tenía la escritura impresa en aquella sociedad de altos índices de analfabetismo impulsó la publicación de numerosas relaciones de fiestas y solemnidades públicas; entre ellas, las bodas de miembros de la Familia Real Española.

\section{LAS BODAS DE LA REALEZA: FUNCIONALIDAD Y FINES}

Sabido es que el matrimonio se constituyó durante el Antiguo Régimen en uno de los pilares fundamentales del sistema monárquico; no en vano, con él se trataba de conseguir tres objetivos de primera magnitud para los intereses de la Corona: mejorar las relaciones internacionales del

Esta práctica de realizar copias manuscritas de las narraciones cortesanas insertadas en gacetas y avisos se constata con cierta asiduidad en España. Vid. BouzA, F., "Cortes festejantes. Fiesta y ocio en el cursus honorum cortesano", Manuscrits, núm. 13 (1995), pág. 191. 
Estado, garantizar la sucesión dinástica y difundir entre los súbditos una imagen humanizada del poder.

Evidentemente, los Borbones utilizaron los casamientos entre miembros de la Casa Real Española e integrantes de otros linajes reales europeos como instrumento diplomático con el fin de incidir directamente en la política exterior del país. A este respecto, valgan como muestra los pactos y enlaces nupciales que se establecieron a lo largo de todo el siglo XVIII con otros linajes reales: Portugal, Francia, Imperio Germánico, Parma, etc. De esa realidad se hacen portavoces las diferentes cédulas emitidas por los monarcas para informar del acontecimiento en cuestión, en las que habitualmente dejaban constancia que la vocación de servicio al Estado era la que les había conducido a establecer las distintas uniones matrimoniales. El propio Felipe V decía casarse con su prima María Luisa Gabriela de Saboya por el "bien de la Cristiandad y la conveniencia de mis Reinos". Del mismo modo, la boda de la Infanta María Luisa de Borbón con el Príncipe de Parma se llevó a efecto para aumentar los vínculos familiares y consolidar la concordia y la paz entre ambas dinastías, tal y como se desprende de la Real Cédula expedida por Carlos IV en San Lorenzo de El Escorial el 5 de noviembre de 1795:

"Asimismo para que se aumente y estreche con nuevos y más fuertes vínculos de parentesco que felizmente hay entre mi Real Familia, y la de los Serenísimos Príncipes de Parma, Plasencia y Gustala, y que se afirmen y permanezcan en ambas la amistad, amor y buena correspondencia que tanto importa, tratamos y acordamos Yo, y el infante Duque de Parma, unir en matrimonio a mi muy amada hija la Infanta Doña Maria Luisa, previa la voluntad y complacencia de su Augusta Madre, my muy cara y amada Esposa, con el Serenísimo Príncipe Don Luis, hijo de dicho Infante Duque y heredero de sus Estados. Y estando convenidos y conformes en los Tratados de Capitulaciones matrimoniales ${ }^{2}$...".

No cabe la menor duda que los intereses políticos primaron sobre cualquier otro argumento a la hora de elegir cónyuge. El amor y el cariño entre los contrayentes difícilmente podía darse antes del casamiento si se tiene en cuenta que, con frecuencia, casi el único conocimiento que poseía el uno del otro simplemente se trataba de un retrato, que en más de una ocasión tenían la oportunidad de ver después de haberse pactado las condiciones de la boda, precisamente el mismo día en que se procedia al acto solemne de petición de matrimonio y en unas circunstancias ajenas a

\footnotetext{
2 Archivo General de Indias (AGI), Gaceta de México, Gacetas 15/7, tomo VIII, núm. 8 (31 de marzo de 1796), págs. 60-61.
} 
cualquier posibilidad de intimidad. Así sucedió en 1738, como era costumbre, con los desposorios de Carlos de Borbón - Rey de las Dos Sicilias y, con posterioridad, Rey de España-, al que conoció la Infanta de Polonia Doña María Amalia de Sajonia - su futura esposa - mediante un retrato que le enseñó el Conde de Fuenclara, quien actuó como embajador representando al monarca en todo el ceremonial dispuesto en la Corte Polaca:

“El día 8 por la tarde a las cinco, que era la hora señalada para la Audiencia, en que avia de pedir la Real Esposa para S.M. de las dos Sicilias vino a buscarle (al Conde de Fuenclara) el Conde de Frise con la propia comitiva del antecedente, y conduciéndole por las principales calles, fueron al Real Palacio... le indroduxo al Quarto del Rey, desde donde, concluida la Función, passó al de la Reyna, y fue recibido en él por su Mayordomo Mayor Conde de Uratiflau; y aviendo hecho una reverente expressión a S.M.P. continuó la más rendida con la Real Esposa, que igualmente le respondió con términos precissos y proprios de su soberania, modestia y agrado. Pidió entonces permisso a S.M.P. para presentar a la Real Esposa el Retrato de Monarca de las dos Sicilias; y tomándole de uno de sus gentiles hombres, que le tenia sobre una almohada de terciopelo carmesí bordada y sembrada de flores de lis, de oro, le ofreció respetuoso a la Real Esposa besándola al mesmo tiempo la mano, en manifestación de su postrada obediencia, y justo alborozos ${ }^{3}$.

Junto al papel jugado por las bodas en las relaciones internacionales, es preciso destacar que los enlaces entre miembros de la realeza también cumplían con la función de asegurar la sucesión dinástica y contribuir al mantenimiento de la castidad conyugal. En este sentido, la castidad en el seno de la pareja era considerada por el monarca como un servicio a Dios, "Nuestro Señor», y al mismo tiempo era valorada por la sociedad como un ejemplo de comportamiento para los súbditos ${ }^{4}$.

Por su parte, los casamientos reales estaban perfectamente ligados al aparato propagandístico del sistema político, organizándose así como un modelo más de las denominadas "ceremonias de información» (proclamaciones y juras reales, natalicios, cumpleaños, onomásticas, exequias,...). De este modo, la celebración de las bodas tenían la virtud de

\footnotetext{
3 Biblioteca Nacional de España (BNE), Gaceta de México, Z 3785, núm. 130 (septiembre de 1738), págs. 1.038-1.039

La castidad era una virtud que debian exhibir los príncipes y que surgía - según la mentalidad de la época- como resultado de la combinación de otras dos virtudes fundamentales: fortaleza y templanza. Vid. Monteagudo Robledo, M. P., La Monarquia ideal. Imágenes de la realeza en la Valencia Moderna. Valencia, Departamento de Historia Moderna de la Universidad de Valencia, 1995, pág. 88.
} 
particularizar y humanizar la imagen demasiado institucional de la Monarquia que reflejaban otras fiestas públicas; en efecto, el matrimonio tenia en sí mismo un componente familiar que acercaba la personalidad concreta de los componentes de la realeza a los súbditos. En concreto, en Indias, donde la presencia física de la Corona se percibía excesivamente lejana ${ }^{5}$, estas efemérides permitían que el pueblo americano las sintiese con cierta afectividad, provocando así adhesiones que aproximaban a la distante dinastía de los Borbones españoles ${ }^{6}$.

Estas "ceremonias de información", en las que se insertaban los festejos programados con motivo de los enlaces conyugales, junto con la formación transmitida por los maestros a sus alumnos, configuraban un modelo de transmisión de los valores del régimen monárquico. De ahí que el diseño educativo vigente en el mundo hispanoamericano propiciara la difusión del culto político al rey en el ámbito escolar; así lo atestigua de forma clara un fragmento extraído del periódico editado por el ilustrado quiteño Francisco Javier Eugenio de Santa Cruz y Espejo ?:

"Luego ocurre otra pregunta de: ¿Y quién es el Rey? A la qual, con el mayor acatamiento de cuerpo y espíritu, se debe responder, que es nuestro Dueño y Señor natural, el Padre de los Pueblos, por quien subsiste el buen orden, se mantiene la Sociedad, se guarda a cada uno la propiedad, y por influencia soberana y universal reaniman nuestros corazones la Paz y la Seguridad. Por mucho que se diga sobre este asunto queda el maestro muy corto; pero es de su obligación inclinar el tierno corazón de sus niños al amor, obsequio, fidelidad y culto político de nuestro Rey, el Señor Don Carlos IIII (que Dios guarde). No para aquí $V$. Maestro mío, sino que sube más arriba y explica como Dios en el seno de sus misericordias, y en los momentos de sus gracias y bendiciones, nos dió a este Supremo Legislador de la tierra, para que le amemos y para que en su Real Persona adoremos la grandeza y magestad del Altísimo, que tiene en sus manos el corazón de los reyes".

La presencia de los integrantes de la Corona en las colonias americanas se hacía más tangible durante la celebración de las fiestas reales: en este sentido, la colocación de retratos de los Borbones en calles y plazas contribuyó a ello. Siendo las autoridades conscientes de esta realidad. durante las fiestas organizadas en 1768 para celebrar el casamiento del Principe de Asturias Don Carlos y la Princesa Doña Luisa de Parma, el Capitán General Interino de Chile Don Juan de Balmaseda mandó colocar en la Plaza Pública de Santiago los retratos de los contrayentes con objeto - -según la documentación-que se les rindiese "el culto político que les corresponde". Archivo Nacional de Chile (ANCH). Fondo Claudio Gay, volumen 36, tolio 137.

En Chile, como constata Isabel Cruz, a diferencia de lo que sucedia con las fiestas organizadas para conmemorar las victorias militares, "los nacimientos, bautizos y matrimonios humanizaban a la monarquia, le imprimian a los ojos de sus súbditos americanos un carácter casi familiar". Chuz de AmEnABAr, I., La fiesta: metamorfosis de to cotidiano. Santiago. Ed. Universidad Católica de Chile, 1995, pág. 245.

Primicias de la Cultura de Quito, núm. 1 (Suplemento, 5 de enero de 1792). 
Con toda naturalidad se recogen en este texto un conjunto de recomendaciones, que si bien iban dirigidas a los docentes americanos, sintetizaban también las conductas-modelos que los organizadores de las fiestas reales trataban de impregnar en los súbditos. De esta manera, en las celebraciones públicas, mediante un lenguaje simbólico, se representaba al monarca como garante de la propiedad, la paz y la seguridad, al tiempo que en el marco de un ambiente festivo se instaba a todos los grupos sociales a que obedeciesen al Rey en su calidad de «Padre, Dueño y Señor natural» y a que le prestasen amor y fidelidad por su condición de "Supremo Legislador" que había sido concedido al pueblo por la misericordia de Dios. Desde luego, se trata de un programa ideológico que integraba a buena parte de los principios sustanciales sobre los que se asentaba la continuidad del régimen monárquico -incluido el origen divino del poder-, y que, por tanto, la dinastía borbónica no dudó en exaltar tanto en España como en América promoviendo la conmemoración de acontecimientos relativos a la Familia Real a través de reales cédulas remitidas a las diversas instituciones y cabildos municipales.

\section{RITOS Y CEREMONIAS MATRIMONIALES}

El ceremonial de las bodas de la realeza sintetizaba en sí mismo los objetivos ideológicos que pretendian consolidar las monarquías europeas; por un lado, posibilitaba la divulgación de los mensajes relacionados con la dominación interna de la población y, por otro, permitía ofrecer una imagen exterior del país en la que primaba la idea de cohesión y unidad entre el poder político y el pueblo.

Como muestra del peso específico que tuvo la política exterior en las bodas reales basta citar el protagonismo que se le concedió a los embajadores; es decir, a los representantes más cualificados del Estado y de la Corona en el extranjero. Al embajador correspondía encarnar simbólicamente a la persona del Rey o del Príncipe y, por tanto, en lugar de ellos efectuar la petición formal del enlace conyugal a la casa real de la futura esposa, firmar las capitulaciones, y asistir como observador a la toma de dichos y a los desposorios; todo ello realizado mediante poderes en el lugar que tuviese a bien fijar la familia real de la novia - habitualmente en su pais de residencia-.

Esta situación preeminente de los embajadores se manifestaba especialmente en el recibimiento que se les ofrecía en la Corte -ya fuese española o extranjera-y en el lujoso cortejo que los acompañaba. De ello es exponente la magnificencia exhibida en el recorrido realizado por las 
calles de Madrid en dirección al Palacio Real por el Marqués de Abrantes -embajador extraordinario de Portugal-y su cortejo, con motivo del matrimonio entre la Infanta de España Doña María Ana Victoria de Borbón y el Príncipe de Brasil — futuro rey de Portugal, conocido con la denominación de José $\mid$ el Reformador-:

"El día 25 de diciembre del referido año de 727 hizo su entrada pública a cavallo en esta Villa el Señor Marqués de Abrantes, Embaxador extraordinario de Portugal, con un numeroso y lucido séquito de siete carrozas muy ricas, un cavallerizo, doze gentiles hombres, quince pajes, diez ayudas de cámara, sesenta y seis lacayos y cocheros, cinco timbaleros y dos correos, todos vestidos de costosas y diferentes galas y libreas, y fue acompañado del Marqués de Almodóvar, Mayordomo de la Casa del Rey, y del Conde de VillaFranca, Conductor de Embajadores, quienes precedía la Casa Real también a cavallo, según se estila en semejantes funciones; y aviendo llegado a mediodia con todo este acompañamiento a Palacio, en cuya entrada se hizieron los honores practicados en tales casos, tuvo audiencia pública de sus Magestades y Altezas, que le recibieron con especial benignidad y agrado ${ }^{8}$.

Ciertamente, esta grandiosidad lucida ante el pueblo de Madrid y del resto de los reinos de España formaba parte de un entramado de gestos ritualizados que trataba de prestigiar a la Corona; en este sentido, un recibimiento a los embajadores que hiciera gala de una ostentación "digna de reyes" no hacía más que proclamar ante los súbditos que el status del cónyuge extranjero al que venía a representar no desmerecía respecto al linaje de los Borbones españoles. Actos de estas características que divulgasen simbólicamente la ilustre ascendencia de los cónyuges elegidos se hacian indispensables en una sociedad con una mentalidad sustentada en el principio de los casamientos entre iguales, y en la que los códigos visuales que transmitía el poder establecido debían tener la virtualidad de ser asimilables por esa misma sociedad a la que iban dirigidos ${ }^{9}$. Esta convicción animaría probablemente al Duque de San Simón -embajador extraordinario del Rey de Francia-, quien estaba encargado de concertar el matrimonio del soberano galo con la Infanta de España, a preparar una comitiva digna del representante del Rey Cristianísimo que se hallaba compuesta por su hijo y su sobrino -el

BNE, Gaceta de México, Z 3785, núm. 6 (junio de 1728), pág. 44.

En este sentido, como advertía Ángel Rodriguez, la imagen es un recurso pedagógico pero que debe sustentarse siempre en las capacidades contemplativas y perceptivas de la sociedad, aunque sabiéndose explotar para ello las posibilidades de empatía que ofrece la propia mentalidad de la época. Rodriguez SANCHEZ, A., "La percepción social de la monarquia», Manuscrits. núm. 13 (1995), págs. 82-83. 
Conde de Orge-, doce gentiles hombres, doce pajes y veinticuatro oficiales ${ }^{10}$.

Por otra parte, el esplendor exhibido por las comitivas de los embajadores - por supuesto, contemplado públicamente por la población- suponía un reconocimiento desde otras casas reales europeas hacia la dignidad y potencial político de la Monarquía Española. Este mensaje no dejaria de estar presente en el brillante ceremonial dispuesto en 1764 para llevar a efecto la presentación que, con motivo del casamiento entre el Archiduque Leopoldo y la Infanta María Luisa de Borbón, se le hizo en la Corte Española al Conde de Rosemberg -Embajador del Emperador de Alemania-:

"El día 11 de febrero de este presente año salió en un coche de la Real Caballeriza el Marqués de Obieco, Introductor de Embaxadores, a recibir al Exmo. Señor Conde de Rosemberg. Embaxador de sus Magestades Imperiales, y especialmente comisionado de pedir a la Señora Infanta... El día 14 señalado para hacer su Exc. la demanda al Rey de la Señora Infanta en audiencia pública, se dirigió su Exc. desde la casa donde se le previno el hospedaje al Palacio del Buen Retiro.

Dio principio la marcha con el orden siguiente: los tymbales y clarines de las Reales Caballerizas, seis porteros y doce lacayos de su Exc. a pié, doce ayudas de cámara, seis pages, un mayordomo y un caballerizo a caballo; la Carroza del Rey de quatro caballos a guias, en la que iba el Señor Embaxador, el Marqués de la Rosa, mayordomo de Semana, y el Marqués de Ovieco, Introductor de Embaxadores; quatro carrozas del Señor Embaxador; una del Señor Nuncio; otra del Señor Embaxador de Francia; otra del de Nápoles: y las del Mayordomo de Semana e Introductor que cerraban el acompañamiento. La numerosa lucida comitiva del Señor Embaxador, lo rico y primoroso de las libreas, y lo exquisito y costoso de las carrozas merecieron general aplauso. La Carrera fue desde dicha casa a la calle Toledo, entrando por el Arco de la Plaza Mayor, y calle de la Amargura, calle Mayor. Puerta del Sol, Carrera de San Gerónimo, Plazuela de la Pelota a la Cerrada del Retiro, en la qual estaban sobre las armas las dos compañias de granaderos de reales guardias, de infantería española y valona, que hicieron a su Exc. los honores correspondientes. En los succesivos cuerpos de guardias, assí de alabarderos, como de corps, se practicó la misma ceremonia, siendo cumplimentado en ellos por sus capitanes y oficiales subalternos. Los gentilhombres de boca y casa recibieron a su Exc. en el saguán de Palacio, le acompañaron y conduxeron con el mismo Mayordomo e Introductor a la Sala de la Audiencia que le dió el Rey, assistido de toda la Grandeza" "

\footnotetext{
Gaceta de México, núm. 3 (marzo de 1722), pág. 31; en Gacetas de México, México Secretaria de Educación Pública, 1949.

Gaceta de Lima. núm. 13 (4 de julio a 12 de octubre de 1764), págs. 163-164; en Gaceta de Lima, Ed. Corporación Financiera de Desarrollo S.A., 1982.
} 
Realmente, junto a la exaltación de la Corona, las bodas reales demostraban, a los ojos del resto de los grupos sociales, una alianza sociopolítica entre el Soberano y la aristocracia española que todavía continuaba teniendo vigencia durante el período de gobierno de la Dinastía Borbónica. Tal y como se observa en el texto que se ha extractado con anterioridad, las celebraciones matrimoniales supusieron un escaparate privilegiado para que la nobleza pudiera ofrecer su imagen de superioridad respecto a otros estamentos de la jerarquía social; no en vano, en las comitivas y actos públicos que se organizaron con tal motivo los linajes nobiliarios tuvieron la oportunidad de promocionar su estatus social. A este respecto, representantes significados de este estamento ocuparon lugares de preferencia en cortejos y ceremonias en su calidad de mayordomos, introductores de embajadores o simplemente como miembros de la Grandeza de España. En esa carrera por el prestigio social que se observa en la España del Antiguo Régimen la obtención de un nombramiento de embajador extraordinario para representar al Rey en los enlaces conyugales solía ser un encargo apetecido, ya que las distinciones y honores que se le dispensaban en las cortes extranjeras al que lo ostentaba le permitía aparecer ante el resto de la comunidad como una persona con una dignidad muy cercana a la de los linajes reales; por supuesto, de lanzar este mensaje al público asistente a los actos se encargaba un conjunto de estímulos visuales: los "vestidos costosos" y las "diferentes galas y libreas" que envolvían al embajador y a sus acompañantes, la carroza real que ocupaba en los desfiles, los honores que le eran practicados por el Ejército y las compañias de guardias reales, las audiencias otorgadas por los reyes y príncipes en Palacio, así como el ser cortejado por los grandes del Reino, otros embajadores y ministros extranjeros. Desde luego, resultaba ser una ocasión irremplazable para cultivar la egolatría de una nobleza europea que trataba de asemejarse a la Corona en un mundo de las apariencias en el que los diferentes linajes nobiliarios intentaban imitar los comportamientos-modelos de los miembros de la Familia Real.

Precisamente, ese interés por ensalzar la dignidad de su ascendencia social llevó a los embajadores españoles a no reparar en gastos en las empresas de representación de la Monarquía, por lo que destinaban cantidades importantes de sus propios fondos a impresionar al público en los espectáculos que se celebraban, llegando incluso en algunos casos a ser un motivo de endeudamiento de las casas nobiliarias de las que eran titulares ${ }^{12}$. A

Vid. Garcia Hernan, D., La nobleza en la España Moderna. Madrid. Ed. Istmo. 1992, pág. 48 
pesar de los riesgos económicos que conllevaba esta actitud, acostumbraban a financiar bailes, banquetes o refrescos en los que el lujo y la abundancia se evidenciaban como las principales características. Pero los embajadores extranjeros tampoco escapaban del todo a estos hábitos; sirva como prueba la "espléndida" comida que dio en Madrid el Conde de Rosemberg - Embajador del Emperador de Alemania- "a la que fueron convidados los Grandes, embajadores, ministros y principal nobleza" ${ }^{13}$.

Este carácter de Estado que tenían los conciertos matrimoniales de la realeza, se vislumbra - como ya se ha señalado- en la propia intervención de los embajadores, pero también se aprecia con toda claridad en el acto de firma de las capitulaciones. En efecto, en las mencionadas capitulaciones no intervenían directamente los contrayentes sino el monarca; de esta manera, cuando se concertaba el casamiento de un príncipe o de una infanta, el titular del Reino - en persona o a través de sus representantesera quien daba su conformidad al convenio. Por otra parte, esa oficialidad de las bodas reales, apartada de cualquier atisbo de intimidad y privacidad en los cónyuges, quedaba atestiguada sobremanera en el propio acto de firma de las capitulaciones, en el que intervenían personalidades de la más alta jerarquía social y política en calidad de asistentes o de testigos de parte de las casas reales interesadas (consejeros de Estado y del Despacho, jefes de las Casas Reales, grandes de España, embajadores y clero), así como el Secretario de Estado y del Despacho de Justicia -quien leia el documento del convenio nupcial en su condición de representante cualificado de la Administración del Estado-. La presencia de la Iglesia se hacía siempre patente mediante miembros significados de su jerarquia -confesores, cardenales y otros prelados-, quienes participaban como integrantes de un estamento socialmente privilegiado o, en su caso, representando a Su Santidad; fuese de una forma u otra, contribuían con su asistencia a conceder autoridad moral al convenio conyugal ${ }^{14}$.

Gaceta de Lima, núm. 13 (4 de jutio a 12 de octubre de 1764), op. cit., pág. 164

En el texto que se transcribe a continuación se observan las personalidades y estamentos sociales y políticos que participaban en el otorgamiento de las capitulaciones matrimoniales en la Corte Real Española: “Por la tarde bolvió el mismo Embaxador a Palacio, y se otorgaron en presencia de sus Magestades las Capitulaciones Matrimoniales del Sereníssimo Señor D. Joseph Principe del Brasil. con la Sereníssima Señora Infanta Doña María Anna Victoria, siendo testigos y concurrentes a este solemne acto (que leyó el Señor Marqués de la Compuesta, como Secretario de Estado y del Despacho de Justicia) por parte del Rey N. Señor. los xefes de sus Casas Reales, los cardenales y prelados que se hallaron este día en la Corte, y entre ellos el Señor Nuncio de su Santidad. y el Señor Arzobispo de Amida. confessor de la Reyna Nuestra Señora, los consejeros de Estado y del Despacho; y por parte de la M. del Rey de Portugal, los Señores Duques de Medina-Coeli, Medina-Sidonia, Béjar, y Veragua, y el Señor Conde de Benavente. BNE. Gaceta de México, Z 3785. núm. 6 (junio de 1728), págs. 44-45 
De forma semejante a como se procedia a firmar las capitulaciones matrimoniales en la Corte de Madrid se llevaba a efecto en otras cortes europeas; prueba de ello fue el acto celebrado en Lisboa en 1728 con el fin de formalizar el casamiento de la Infanta portuguesa Doña María Bárbara de Braganza con el Príncipe de Asturias -el que más tarde sería denominado Fernando VI al ocupar el trono de España-:

“El día 10 de henero de este año de 728 se otorgaron, en presencia de los Reyes, las capitulaciones matrimoniales del Sereníssimo Sr. D. Fernando, Príncipe de España, con la Serenissima Señora Infanta Doña María Bárbara, las que leyó el Secretario de Estado Diego de Mendoza Corte Real, assistiendo como testigos por parte del Rey de Portugal, los primeros xefes de las Casas Reales; y por parte del Rey Cathólico, los Marqueses de Nisa, Angeya, de Cascaes, de Valenza, y de Alegrete, Manuel Tellez de Sylva, y Pedro de Vasconzelos: a esta función se hallaron presentes los Embaxadores de España, que fueron juntos a Palacio con todo el rico y sumptuoso Tren, y familia del Marqués de los Balbases, quién sacó aquel día nueva y lucida librea, como también assistieron aquel día los cardenales de Acuña y de la Mota, y otros muchos prelados y cavalleros.... ${ }^{15}$.

Una vez formalizado oficialmente el concierto matrimonial, las ceremonias se precipitaban en el tiempo con cierta celeridad de forma que normalmente en las dos jornadas siguientes quedaba totalmente verificado el casamiento por poderes; así pues, el primer dia se tomaba de dichos a la infanta prometida y en el segundo día se realizaban los regios desposorios. En concreto, la bendición nupcial - a pesar de la ausencia habitual del contrayente varón- se practicaba en el Salón de Palacio que dispusiese la casa real de la novia, correspondiéndole efectuarla -en el caso que el acto tuviera lugar en la Corte Española - al Cardenal Patriarca de las Indias. En algunas cortes europeas, tal y como sucedió en el casamiento de Don Carlos de Borbón - Rey de las Dos Sicilias- con la Infanta de Polonia María Amalia de Sajonia el oficio religioso era presidido por el Nuncio Apostólico de Su Santidad, aunque asistido por diferentes prelados del país anfitrión ${ }^{16}$.

\footnotetext{
15 BNE, Gaceta de México, Z 3785, núm. 6 (junio de 1728), pág. 47.

11. En efecto. el ceremonial del casamiento organizado en la Corte de Polonia el 9 de mayo de 1738 contó con la presencia del Nuncio de Su Santidad, a quien acompañaron otros miembros del alto clero y de la jerarquía política del pais: “... se celebró el Desposorio, representando a S.M. de las Dos Sicilias el Príncipe Real y Electoral, y echando las bendiciones el Nuncio Apostólico Monseñor Pauluci, a quien assistieron tres obispos polacos, como a tan plausible Función, sus Magestades y su Real Familia, la más numerosa y distinguida nobleza del pais, de ambos sexos, más de 80 nobles polacos de la primer gerarquia, y un considerable número de ilustres forasteros de Bohemia y Austria". BNE, Gaceta de México, Z 3785, núm. 130 (septiembre de 1738), pág. 1040 .
} 
Todos los aspectos analizados confirman la ausencia de un ambiente familiar en los casamientos reales y, por tanto, la excesiva carga de oficialidad y de rigidez en el protocolo. La boda por poderes ya era una evidencia en sí misma de esta realidad, pero si a ello le añadimos la lista de participantes e invitados en la ceremonia nupcial se elimina cualquier tipo de duda sobre la frialdad afectiva que envolvía a este acontecimiento. Nuevamente nos encontramos, entre los intervinientes y asistentes a este acto -aparte de la Familia Real-, con los ministros españoles y extranjeros, los embajadores, el Nuncio de Su Santidad, la Grandeza de España, y el Secretario de Estado y del Despacho de Gracia y Justicia -este último, como su propio cargo indica representando al Estado en su condición de Notario Mayor de los Reinos, con el fin de legalizar el enlace conyugal-. La narración que nos ofrece la Gaceta de Lima en 1764 detallando los pormenores del matrimonio celebrado en Madrid entre la Infanta María Luisa y el Archiduque Leopoldo - hijo del Emperador de Alemania- explícita estos comportamientos a los que se ha aludido:

"... dio el Príncipe N.S. la mano a la Señora Infanta, su hermana, en nombre del Señor Archiduque, su Esposo, exerciendo de Parrocho el Emmo. Señor Cardenal de la Cerda y San Carlos, Patriarca de las Indias, con assistencia el Exmo. Conde de Rosemberg, del Señor Nuncio de su Santidad, de los demás señores embaxadores, y ministros estrangeros, y de toda la Grandeza. Legalizó este Solemne Acto el Exmo. Señor Marqués del Campo Villar, Secretario de Estado y del Depacho de Gracia y Justicia, como Notario Mayor de aquellos Reynos" ${ }^{17}$.

Como se ha podido comprobar, todas las bodas a las que hemos aludido hasta el presente se insertan dentro del rito católico; no obstante, en otros países europeos en los que se adoptaba el ceremonial protestante también se aprecia una acusada rigidez formal, aunque - salvando algunos cambios lógicos - el protocolo se asemeja al que organizaba la Casa Real Española. Sirva como muestra el relato que se reseña en la Gaceta de Lima en 1756 sobre el enlace nupcial entre el Príncipe Ferdinando de Prusia y la Princesa Ana Isabel Luisa:

"El Príncipe Ferdinando, hermano segundo del Rey de Prusia, contraxo matrimonio con la Princesa Ana Isabel Luisa, hija segunda de el Margrave de Schvedt, en la Capilla Real de Charlotembourg, a donde desde la Sala de este Palacio passó con el orden siguiente: los cavalleros pages y criados de librea del Rey, los mayordomos del Rey y los camareros, el Real Manto, el

Gaceta de Lima, núm. 13 (4 de julio a 12 de octubre de 1764), op. cit., pág. 165. 
Rey, que conducia a la Reyna Madre, la Reyna conducida por el Príncipe de Prusia, la Princesa de Prusia por el Príncipe Henrique, la Princesa Esposa de este último por el Príncipe Federico Guillermo de Prusia, la Margrave de Schvedt por el Príncipe Federico Henrique Carlos, la Princesa de Vourtemberg Stuttgard por el Margrave Carlos, la Princesa Federica Sophia Guillermina de Prusia por el Príncipe de Vourtemberg Stuttgard; y últimamente los Príncipes estrangeros, y los ministros y generales. Mons, Sak, primer Limosnero de la Corte, dió a sus Altezas la bendición nupcial" ${ }^{18}$.

Por supuesto, todo este ceremonial -ya fuese promovido por una casa real $u$ otra - terminaba siendo celebrado en las diferentes cortes europeas con diversos festejos, que en el caso de España incluian normalmente banquetes, bailes, fuegos artificiales, luminarias, teatro y conciertos musicales. Precisamente los convites centralizaron los agasajos y atenciones que se les ofrecia a los invitados en las bodas, independientemente de que la organización de ellos correspondiese a la Casa Real Española, al embajador extraordinario que representaba al otro cónyuge o, en su caso, a otras casas reales regidas por la Dinastía Borbónica. De esta manera, en las noches siguientes al matrimonio se sucedían diferentes banquetes a los que asistian como invitados la Grandeza de España, embajadores, ministros y "personas de mayor distinción", a quienes se les preparaba "refrescos», cena y prolongados bailes que duraban hasta el amanecer ${ }^{19}$.

Gaceta de Lima, núm. 3 (9 al 28 de junio de 1756), op. cit., pág. 19.

Esta costumbre de agasajar a los invitados de las bodas reales con banquetes -amenizados habitualmente con bailes, teatro y conciertos musicales- estaba extendida en las cortes europeas. En concreto, la celebración de los desposorios de María Amalia de Sajonia con el Rey de las Dos Sicilias se practicó en Polonia de esta manera: "Siguiose luego la cena, ocupando la primera mesa sólo las personas reales, la Princesa de Weisenssels, que es de esta augusta familia, el Nuncio, el Conde de Fuenclara (Embajador del Rey Carlos de Borbón), y el Embaxador Imperial: y en otras fuera de aquella Sala, las damas y cavalleros de la Corte, y después el bayle que comenzó S.M.P. con la Reyna de las Dos Sicilias, y duró hasta las doce de la noche. El dia 10 se festejó con un torneo... Fue la cena aquella noche en el quarto del Príncipe Real, y en la del dia 11 se cantó una célebre opera con magníficas y primorosas decoraciones". BNE, Gaceta de México. Z 3785. núm. 130 (septiembre de 1738), págs. 1.040-1.041.

En parecidos términos se llevaron a efecto los festejos realizados con motivo del casamiento del Principe Ferdinando -hermano del Rey de Prusia-: "A las nueve se tuvo el Festin Real en la gran Sala del Palacio. Los príncipes, las dos reynas, los nuevos esposos, los príncipes y princesas de la Familia Real, y los Príncipes de la Sangre, concurrieron solos a el Banquete; cuya mesa, que se compuso de veintiquatro cubiertos, se sirvió con vaxilla de oro. Huvo otras cinco mesas que se armonizaron con el cumplido de docientos cubiertos. A la cena succedió un baile de ceremonia en el qual llevaron las hachas los ministros de Estado, de dos en dos. El siguiente día... se concluyó con el subsecuente de una cena a toda esplendidez y riqueza, la que terminó un baile. El dia siguiente se tuvo otro sumptuoso banquete en seis mesas, y por la noche se representó el sainete o intermedio italiano intitulado La Maestra Escuela, y después de una gran cena se comenzó el baile que duró hasta cerca del amanecer. El postrero dia se tuvo otro banquete magnífico; después del qual se restituyó el Rey a Postdam, las reynas a Berlim, con los príncipes recién casados y el resto de la Familia Real». Gaceta de Lima, núm. 3 (9 al 28 de junio de 1756), op. cit., págs. 19-20 
Con todo, el último acto del enlace conyugal solía ser la entrega de la infanta o princesa o, en su caso, de la reina al esposo. Dado que el matrimonio se realizaba por poderes en la corte de la novia, una vez concluidos los festejos - normalmente varios dias después de los desposorios- se preparaba una comitiva con el fin de llevarla al país de residencia de su marido. Por supuesto, el viaje no estaba exento de dureza, ya que en ocasiones era preciso atravesar varios paises antes de llegar a la nueva corte que debía acogerla ${ }^{20}$; si bien el recorrido encontraba las dificultades que imponía el medio físico, es cierto que el diseño propagandístico de la Monarquía Española supo aprovechar estas largas jornadas de camino para extender entre los súbditos, en las diferentes villas y ciudades por las que pasaba la Comitiva Real, el gozo por el casamiento regio. Esa convicción pedagógica de la Corona con respecto al pueblo le impulsaría a organizar extensos y lujosos cortejos para acompañar a las recién casadas como el que se le preparó a la Infanta de España María Ana Victoria -Princesa del Brasil tras su enlace nupcial-; en concreto, en su insigne séquito iban integrados los Reyes de España, el Príncipe de Asturias, los infantes, los jefes de las casas reales, oficiales de infantería y de guardias de corps, gentiles hombres de cámara, camareras mayores, damas y señoras de honor, azafatas y camaristas de la Reina y de la Princesa, el Cardenal Patriarca de las Indias, el Capellán Real y Limosnero Mayor de su Majestad, y otros capellanes de honor, mayordomos reales, caballeros pajes del Rey, todos los "oficios de la boca" de la Casa Real, caballerizos y miembros de la nobleza ${ }^{21}$. Desde luego, situaciones como las que justificaban este recorrido de la Familia Real, a través de las diferentes localidades de Castilla y Extremadura que encontraron en su itinerario, propiciaron el acercamiento de la Corona al pueblo; no en vano, esa presencia física animaba a los españoles a rendir culto a la realeza. Así sucedió, al menos, cuando los Reyes de España entraron en la ciudad de Badajoz con motivo de las recíprocas entregas de la Princesa de Brasil y de la Princesa de Asturias que se iban a efectuar en la Frontera con Portugal; en efecto, el día que entraron Sus Majestades y Altezas en la localidad extremeña fueron recibidos, según consta en los testimonios recogidos en la prensa periódi$\mathrm{ca}$, «con las alegres demostraciones correspondientes a la fidelidad y

Precisamente. la Reina Maria Amalia de Sajonia. una vez finalizada la ceremonia nupcial y los festejos organizados en Polonia, debió cubrir - junto al cortejo real que la acompañaba- una larga distancia antes de encontrarse con su nuevo marido en Nápoles. BNE. Gaceta de México, Z 3785, núm. 130 (septiembre de 1738), pág. 1041

BNE. Gaceta de México, Z 3785. núm. 19 (junio de 1729), págs. 150-151 
amor de los vezinos de aquella Plaza, y de los comandantes, oficiales y soldados de su guarnición» 22.

Por su parte, el acto de entrega de las recién casadas tampoco estaba ajeno a la magnificencia y esplendor que se exhibía en todo el ritual que rodeaba a las bodas reales. Especialmente elocuente de ello fue la entrega de las princesas antes mencionadas en la Frontera HispanoPortuguesa; puesto que, con tal fin se hizo un gran despliegue militar y se construyó expresamente para la ocasión un puente de madera sobre el Río Caya y una "casa de entregas" lujosamente decorada con vidrios, pinturas y molduras doradas. De la suntuosidad y solemnidad de este acto nos informan con todo detalle los testimonios publicados en las gacetas de la época:

«... y aviéndose señalado para esta función la tarde del miércoles 19 salieron de Badajoz después de comer, en una rica y primorosa carroza los Reyes, la Señora Princessa del Brasil, el Principe nuestro Señor y los señores infantes D. Carlos y D. Phelipe, a quienes seguían con grande orden y extraordinario lucimiento todos los coches de respecto... y séquito que acompañan a sus Magestades en la Corte quando salen en público. Aviase fabricado para esta gran ceremonia un dilatado puente de madera sobre el rio Caya, que divide los Reynos de Castilla y Portugal, y dista una legua de Badajoz, y sobre el puente estaba construida la casa de las entregas, de figura cuadrada, con muchas ventanas de vidrios cristalinos, y toda vistosamente pintada, y por dentro y fuera con muchas tarjetas, festones y molduras de talla dorada, y con las Armas de ambos reynos. En las fachadas correspondientes, y de esta parte del Rio Caya, estaban formadas, y en admirable orden, las tropas de la Casa Real y otras del Exército de Estremadura, que excedian el número de seis mil hombres, todos bien vestidos y armados, precedidos de los esquadrones de las guardias de corps y de los batallones de los regimientos de infantería española y valona; de la otra parte del río se vieron también formados algunos muy lucidos regimientos portuguesses. $Y$ quando sus Magestades y Altezas llegaron junto a la casa de las entregas ya estaban aguardando de el otro lado los Reyes. Principes e infantes de Portugal, que todos venían en una misma carroza, y seguidos de muy numerosa y ricamente adornada comitiva; de suerte que immediatamente entraron en el aposento interior de la casa los Reyes, Reynas, Príncipes, Princessas e Infantes, que todos eran treze personas reales, y después de averse abrazado y cumplimentado con indecible cariño se leyeron las capitulaciones y tuvieron una agradable conferencia de más de una hora. Luego se bolvieron a Yelves los Reyes de Portugal, con los principes y la Princessa del Brasil y con los tres infantes, y los Reyes y príncipes nuestros Señores, se bolvieron a Badajoz..." 23.

BNE, Gaceta de México, Z 3785, núm. 20 (julio de 1729), pág. 157.

BNE, Gaceta de México. Z 3785, núm. 20 (julio de 1729). págs. 157-158. 
Terminado el acto de entrega se encontraban por fin los contrayentes y se procedía a la velación y ratificación de los desposorios regios en presencia de un prelado de la Iglesia. Comenzaba entonces un período de conocimiento mutuo de los dos componentes de la pareja dentro de un ambiente de mayor intimidad y privacidad; no obstante, el matrimonio ya se habia consumado legalmente y quedaba por delante una larga convivencia cuyos resultados afectivos difícilmente eran previsibles en unos cónyuges que normalmente no habían tenido la oportunidad de entablar ningún tipo de relaciones de noviazgo con anterioridad.

Como se ha podido apreciar, en este variado ceremonial organizado para celebrar las bodas reales se producian manifestaciones de adhesión a la Corona; no obstante, el protocolo hacía más patentes estas manifestaciones durante los actos institucionales de besamanos y felicitación. Ya fuese después de concertadas las capitulaciones matrimoniales o tras oficiarse los desposorios, los máximos representantes de las instituciones del Estado y de la Capital del Reino - es decir, los miembros de los consejos y tribunales de la Corte, los integrantes del Cabildo de la Villa de Madrid y otras personalidades políticas y sociales-, acostumbraban a pasar por Palacio para cumplimentar con felicitaciones y besamanos al Soberano y a la Familia Real. Por supuesto, este protocolo que se guardaba en la Corte Española resultaba ser muy semejante al que se atestigua en otras monarquías europeas; así se advierte, al menos, en el acto que se realizó en Lisboa después del casamiento de la Infanta Doña Bárbara de Braganza con Fernando -entonces Príncipe de Asturias-:

"El lunes concurrieron en Palacio el Señor Patriarcha, el Señor Cardenal Acuña, los embaxadores y ministros estrangeros, los consejos y tribunales, los prelados de las religiones, y toda la nobleza, para cumplimentar a sus Magestades y a la Señora Infanta Doña María Bárbara, ya Princessa de España...» 2.4 .

Realmente, esa misma adhesión que rendian los representantes de las instituciones de la Administración Central Española a la Corona se materializaba también en tierras americanas. Todas las autoridades políticas y religiosas, así como la nobleza, trasladaban al respectivo virrey —único alter ego del monarca- el gozo y felicidad que habían causado los matrimonios de la realeza en las poblaciones en las que residían; desde luego, estos acontecimientos de miembros de la Familia Real funcionaban como estímulos que activaban un mecanismo de articulación y cohesión de vo-

BNE. Gaceta de México, Z 3785. núm. 6 (junio de 1728), págs. 47-48. 
luntades a lo largo de todo el Imperio Español. Muestra de ello fueron las múltiples felicitaciones que llegaban al virrey mediante comisarios enviados por los diferentes cabildos eclesiásticos y seculares; asi sucedió, como no podia ser de otra forma, con los "cumplimientos" recibidos por el virrey de Nueva España, en su Corte de México en 1722, con motivo de las bodas del rey de Francia con la Infanta de España y del Príncipe de Asturias con una Infanta del vecino país:

"Llegaron a esta Corte los señores D. Antonio Navarro y Dr. D. Gaspar Mendes de Cisneros, canónigo y racionero de la Ciudad de los Ángeles, en nombre de su M. Ilust. Dean y Cabildo Sede-Vacante, a cumplimentar al Exc. Señor Virrey y expresarle de su parte el fidelíssimo gozo y deseo de el logro de las felicidades que promete la amistosa unión de ambas coronas en el lazo agradable de los dichosos consorcios de nuestros amantíssimos Príncipes... El día 22 llegaron cartas del Nobilissimo Ayuntamiento de la Ciudad de la Puebla para los señores que componen el de esta de México, dando noticias de venir dos señores commissarios de sus capitulares, que fueron D. Joseph Gorospe Irala, regidor, y D. Antonio de Artiaga y Frias, Depositario a los debidos expressivos por las mencionadas nupcias; y aplazados señalaron por este Cabildo a dos señores regidores, que fueron el Conde de el Valie de Orizava y D. Juan de Coz y Zeballos, para reproducir los cumplimientos de una ciudad a otra, y aviendo llegado a esta Corte y obtenido licencia de el Exc. Señor Virrey, passaron con todo este Cabildo, en forma de ciudad, con la authoridad de tiros largos, y los tenientes a cavallo, y los porteros con ropones de terciopelo carmesi y mazas de plata, a conducir a los dichos commissarios hasta el Real Palacio, donde desempeñaron la congratulación de su ciudad, en cuyo nombre passaron al día siguiente a agradecer a estos señores la concurrencia de sus urbanidades, correspondiéndose reciprocamente los cumplimientos" ${ }^{25}$.

Ciertamente, todo este conjunto de actos y ceremonias programadas en la capital del Imperio y en el resto de las localidades hispanoamericanas mostraban una imagen de la Corona - a veces excesivamente idealizada-, pero que indudablemente contribuía a fortalecer los vínculos de unión existentes entre los diferentes grupos sociales y la Monarquia Hispánica, así como entre ésta y el resto de las casas reales europeas.

\section{LA PRESENCIA DE DIOS Y DE LA IGLESIA EN LAS FIESTAS NUPCIALES}

Las celebraciones festivas que tuvieron lugar durante el Setecientos en los territorios integrados en la Monarquía Española continuaban evi-

Gaceta de México. núm. 6 (junio de 1722). op. cit, págs. 54-55. 
denciando que lo religioso y lo público eran dos facetas que estaban íntimamente ligadas. La visualización de esta alianza tuvo como exponente la participación de la jerarquía eclesiástica en todos los actos organizados con motivo de los casamientos regios, con independencia de que el contenido de ellos fuese espiritual o profano. En este sentido, ya se ha reseñado la presencia del alto clero - cardenales, arzobispos, obispos y confesores reales- en el ritual matrimonial que se practicaba en la Corte de Madrid; si bien los "buenos oficios" de los clérigos eran indispensables para santificar los enlaces conyugales, también es cierto que la asistencia de este estamento a banquetes, cortejos y otras manifestaciones festivas no respondían a criterios espirituales sino a condicionantes puramente sociales y políticos.

Esa imagen nítida de la unidad entre lo religioso y lo temporal, de la que eran conscientes los españoles del Antiguo Régimen, contribuía a diseñar un sistema político que descansaba en Dios como origen y fin último del poder ${ }^{26}$; de ahi que incluso los reyes, dentro de la propia mentalidad de la época, tuviesen la necesidad moral de pedir ayuda y colaboración a la Divinidad para el ejercicio de las tareas de gobierno. Por supuesto, sabido es que un convenio matrimonial era un instrumento de alta política de Estado y que, por tanto, requería contar con el aval del Todopoderoso; quizás esa convicción llevaría a organizar a lo largo del Imperio Español diferentes ceremonias encaminadas a que los súbditos - también hijos del Creador- hiciesen sus plegarias y diesen gracias por los beneficios que les podía reportar los casamientos reales. De este modo, en la propia Corte Española, durante los días en que se celebraban los regios desposorios, se ofrecía una "acción de gracias» consistente habitualmente en una función religiosa en la que se cantaba el Te Deum y, en ocasiones, la Salve. En este contexto, resultaron especialmente solemnes las plegarias dirigidas, por parte de los miembros de la Familia Real y de su séquito, a Dios y a la Virgen en la Capilla de Nuestra Señora de Atocha como consecuencia del matrimonio concertado entre el Archiduque Leopoldo y la Infanta de España Maria Luisa:

“... y por la tarde pasaron en público el Rey y Príncipe, nuestros Señores, con la Señora Infanta Doña María Luisa y demás personas reales, a excepción de la Reyna Madre, Nuestra Señora, a dar gracias al Altíssimo a su Real Capilla de Nuestra Señora de Atocha por el efectuado matrimonio de la señora infanta Doña María Luisa..., quienes, habiendo entrado en ella, assistieron al Te Deum y Salve que cantó la Música de la Real Capilla. 
Concluido este devoto acto volvieron el Rey y su Augusta Familia a tomar las carrozas para restituirse, como lo executaron, al Palacio de Buenretiro, por el camino de Prado" 27.

La Corona propició que estas peticiones a la Divinidad se extendiesen a todos sus reinos; para ello enviaba continuas reales cédulas ordenando a las distintas autoridades territoriales — virreyes, intendentes, alcaldes, etc.- que los respectivos párrocos de las diferentes ciudades, villas y lugares oficiasen misas solemnes de acción de gracias ${ }^{28}$. En concreto, en las poblaciones americanas se detecta que los actos organizados adquirieron una complejidad y pompa que superaban las propias recomendaciones de las órdenes reales; tanto es así que en algunas localidades las autoridades civiles y eclesiásticas no se conformaban con el oficio de una misa acompañada del pertinente sermón y Te Deum, sino que además incluian en el ritual otros actos litúrgicos de mayor duración como los novenarios ${ }^{29}$. De esta forma, en las catedrales e iglesias de América el pueblo en general ${ }^{30}$, la nobleza y las autoridades que representaban a las distintas instituciones - cabildos, tribunales y administración virreinal - se unian a la Corona dando gracias a Dios por los beneficios que proporcionaban al Estado los matrimonios de la realeza y rogando, asimismo, por la felicidad de los contrayentes.

Gaceta de Lima, núm. 13 (4 de julio a 12 de octubre de 1764), op. cit., págs. 166-168.

De este hecho se hace eco el relato publicado en México el 31 de marzo de 1796 en que se intorma sobre el casamiento de la Infanta María Luisa con el Príncipe de Parma: "En su cumplimiento y para que se hagan notorias a todos tan plausibles e interesantes noticias, mandó (el Virrey de Nueva España) se publique por bando y se remitan los exemplares necesarios a los señores intendentes a fin de que dispongan también su promulgación en las demás ciudades, villas y lugares de su distrito, con el justo objeto de que en todas partes se celebren en la forma acostumbrada, reduciéndose las demostraciones de júbilo que deberán hacerse a tres dias de iluminación, cortinas y repique general, acordando con los respectivos párrocos se celebre en uno de estos dias misa solemne de gracias, que se verificará en esta capital el 30 inmediato, y en éste y los dos precedentes. 28 y 29. se harán las enunciadas demostraciones con la decencia y decoro correspondientes. AGI, Gaceta de México, Gacetas 15/7, tomo VIII, núm. 8, págs. 60-61.

Asi sucedió en San Germán de Puerto Rico, dónde se celebró el casamiento de Luis I mediante un novenario y misas cantadas "con abundancia de luces y patente el Santísimo Sacramento del altar, gran concurso de gente e instrumentos y villancicos bien curiosos". LOPEZ CANTOS, A. Juegos, fiestas y diversiones en la América Española. Madrid, Ed. Mapfre, 1992, págs. 118-119.

Como ejemplo ilustrativo de la participación de los diferentes estamentos sociales y politicos en las ceremonias de acción de gracias son esclarecedores los actos organizados en la Catedral de Oaxaca con motivo de los enlaces nupciales entre miembros de las casas reales de España y Portugal: "El Ayuntamiento de esta ciudad dio principio el día siete de este noviembre a las fiestas de los recíprocos casamientos de los Sereníssimos Príncipes de España y Portugal, con lucidissimo acompañamiento de toda la nobleza e innumerable concurso que concurrió en la Santa Iglesia Cathedral, en donde cantó la missa de gracias el Ilmo. Sr. Dr. D. Joseph Félix Valverde, Deán de ella, colegial que fue del Real de San Ildephonso de México y obispo electo de Caracas...» BNE, Gaceta de México, Z 3785, núm. 12 (noviembre de 1728), pág. 94 


\section{PARTICIPANTES Y ORGANIZADORES}

La iniciativa de promocionar las fiestas conmemorativas de los desposorios regios correspondió siempre a la Corona, quien no desaprovechó ninguna ocasión propicia para que los súbditos mostrasen el «cordial afecto" que sentían hacia la Familia Real. En concreto, la transmisión de esta iniciativa se llevaba a efecto utilizando canales institucionales que se activaban inmediatamente después de que el monarca comunicaba mediante reales decretos a los diferentes consejos territoriales -en el caso de América, al Consejo de Indias - la noticia de los conciertos matrimoniales. Desde el Consejo de Indias se daba traslado de las reales cédulas a todos los dominios de América mandando a virreyes, presidentes y reales audiencias, gobernadores, intendentes, corregidores, cabildos municipales y prelados eclesiásticos que hiciesen cumplir la voluntad del Soberano ${ }^{31}$. A pesar de ello, fueron los ayuntamientos - tanto en España como en América - los encargados de comunicar directamente a los vasallos de la Monarquía Española las noticias de los enlaces nupciales; con tal fin, se redactaban bandos que recogían los actos programados, las motivaciones de la celebración y las obligaciones de los vecinos -limpieza y adorno de calles, asistencia a los actos, etc.--. Asimismo, también correspondía a los cabildos municipales adoptar todas las providencias necesarias y nombrar a los comisarios que tendrían que ocuparse de la organización de los festejos.

Si bien en España las fiestas se preparaban con cierta inmediatez a la promulgación de las reales cédulas, en Indias se demoraban en exceso, ya que la noticia llegaba al otro lado del Atlántico con demasiada tardanza - una media de seis meses después de finalizar las nupcias ${ }^{32}$ -

El texto que a continuación se extracta expresa de forma sintética los conductos oficiales que seguian las reales cédulas para comunicar las noticias a las autoridades americanas: “... se efectuaron ambos desposorios en el dia veinte y cinco de agosto último, según lo participé a mi Consejo de las Indias por reales decretos de veinte y veinte y seis del propio mes, para que me acompañase en el regocijo que me causan estos matrimonios, de que espero se sigan conseqüencias muy favorables a nuestra Santa Fe, a mi Corona y vasallos; y habiendo mandado se comuniquen estas plausibles noticias a aquellos mis dominios para que se hagan más notorias. como se acostumbra en semejantes casos, he resuelto expedir esta mi Real Cédula, por la cual mando a mis virreyes, a los presidentes y reales audiencias de aquellos distritos y las Islas Filipinas, y ruego y encargo a los respectivos prelados eclesiásticos que cada uno en su jurisdicción to haga publicar al fin expresado. Fecha en San Lorenzo, a cinco de noviembre de mil sete cientos noventa y cinco. Yo el Rey. AGI, Gaceta de México, Gacetas 15/7, tomo VIII, núm. 8 (31 de marzo de 1796), págs. 60-61.

32 En ocasiones excepcionales se constata una demora superior a los nueves meses. Vid. Lopez Canios, A., op. cit., pág. 194. 
Previamente era demasiado habitual que se tuviese conocimiento de estos eventos a través de la correspondencia privada o gracias a informaciones divulgadas por viajeros y marineros españoles o extranjeros. Esta acusada lentitud del correo oficial permitió que fuesen conocidos en el Puerto de Veracruz los conciertos matrimoniales entre las casas reales de España y Francia dos meses antes, al menos, que llegase la notificación de la real cédula; en esta ocasión la información la proporcionó una fragata que arribó en marzo de 1722 al citado puerto transportando media carga de sal desde Campeche, la cual extendió la noticia de la "feliz salud de sus Magestades, y de averse ajustado el casamiento de el Príncipe nuestro Señor con la Señora Infanta, hija del Señor Duque de Orleans, y el de la Señora Infanta de España con su Magestad Christianíssima» ${ }^{33}$.

Sin duda, el objetivo que trataba de conseguir la transmisión de estas órdenes reales era recordar el estricto cumplimiento del precepto de rendir culto político al Soberano y de obedecer su voluntad ${ }^{34}$. En ese contexto de deber cívico se instaba, desde la Capital de España, a que los súbditos demostraran su amor y afecto a la Monarquía dentro de un ambiente de alegría y de "regocijos que causaban estos matrimonios"; asi se consolidaban y se reafirmaban los vínculos entre la Corona y el pueblo, pues las fiestas ofrecían la posibilidad de compartir el gozo de la Familia Real y, por tanto, de abandonar durante unos días la dureza de la cotidianeidad participando en los espectáculos públicos de carácter gratuito que las autoridades y los diferentes estamentos ponían al servicio de la estudiada propaganda regia con objeto de excitar los "leales ánimos de los vasallos".

La real cédula no fue conocida por el Cabildo de Veracruz hasta el 15 de mayo de 1722. día en que llegó el correo oficial al puerto de esta ciudad; por supuesto, ya la prensa periódica - gracias a la información obtenida de la fragata procedente de Campeche- había divulgado estos regios conciertos matrimoniales. Gaceta de México, núm. 3 (marzo de 1722), op. cit.. pág. 29.

is La documentación y la prensa periódica se hacen eco de que la participación en las fiestas organizadas con motivo del casamiento de algún miembro de la Familia Real era considerada como una obligación o precepto. Así lo demuestra la Orden firmada por el Capitán General Interino de Chile el 16 de septiembre de 1768 con objeto de celebrar el enlace nupcial entre el Principe de Asturias Don Carlos y la Princesa Doña Luisa - hija del Intante Don Felipe. Duque de Parma-: "Debia de mandar y mando se publique esta orden en forma de vando en las plazas públicas y lugares acostumbrados para que llegue a noticia de todos, y cada uno por su parte concurra como es debido al zelo y lealtad a Ntro. Soberano, bajo de los apercebimientos que en mi reserbo..." ANCH, Fondo Claudio Gay, volumen 36. folio 137.

Por otra parte, el relato de los actos preparados en la ciudad de Tlascala en 1729 también atestiguan esta evidencia: "Aviéndosele ordenado por S.M. a el Cabildo y Regimiento de esta ciudad celebrase los reciprocos consorcios de los Sereníssimos Señores Príncipes de España y del Brasil, en obedecimiento a tan soberano precepto, se han celebrado con todo lucimiento..." BNE. Gaceta de México, Z 3785, núm. 18 (mayo de 1729), pág. 142. 
En lo que respecta a la Corte de Madrid, la coordinación de las ceremonias y festejos correspondía a la Casa Real Española; sin embargo, ésta supo distribuir las responsabilidades y los costes económicos haciendo partícipes, entre otros, al embajador extraordinario que representaba a la casa real del cónyuge extranjero, al Cabildo de la Villa de Madrid y a los embajadores de otros países en los que, de igual modo que en España, reinaba la dinastía de los Borbones -Francia y Reino de las Dos Sicilias-. Con todo, la Corona asumía los gastos generados por diversos actos de carácter protocolario y festivo que dependían directamente de ella: suntuosos cortejos y comitivas reales, ceremonias de entrega de princesas, loas y comedias representadas inmediatamente después de la bendición nupcial, refrescos, cenas, bailes, así como la recepción y comida de bienvenida ofrecida al embajador extraordinario que encarnaba a la casa real del cónyuge extranjero - un banquete al que también asistian otros embajadores, ministros y la Grandeza de España ${ }^{35}$. . Por su parte, la villa de Madrid, manifestaba el júbilo que producía en los vecinos las bodas reales encargándose, entre otras cuestiones, de la financiación de los fuegos artificiales y luminarias que contribuian a realzar el escenario público en el que se llevaban a cabo los festejos.

Otras casas reales europeas gobernadas por la dinastía Borbónica dejaban constancia expresa del gozo y alegría que les causaba los enlaces nupciales de miembros de la Familia Real Española; no en vano, se trataba de casamientos de integrantes del mismo linaje. Los actos patrocinados por los embajadores de Francia y del Reino de las Dos Sicilias para celebrar los desposorios del Archiduque Leopoldo y la Infanta María Luisa en la Corte de Madrid testimoniaban esta realidad:

"La noche del día 22 (enero de 1764) manifestó también el Exc. Sr. Príncipe de la Católica, Embaxador del Rey de las Dos Sicilias, la mucha parte de gozo que tomaba su Corte en el efectuado matrimonio, con un abundantissimo refresco, fiesta de teatro en idioma español, cena expléndida y delicada, y baile; correspondiente todo a lo digno del motivo... Este último día (24 de enero), por serlo señalado al Exc. Dr. Marqués de Ossun, Embaxador de S.M. Christianissima, para expresar el regosijo por su Corte, concurrieron convidados a casa de S. Exc. los Grandes, embaxadores, mi-

\footnotetext{
La alta nobleza española colaboró con la Corona en la coordinación y organización de las ceremonias y festejos nupciales. Así sucedió en 1764 en los actos organizados en Madrid con motivo del casamiento del Archiduque Leopoldo con la Infanta María Luisa, en los que el Marqués de Montealegre - Mayordomo de su Majestad- dio una espléndida comida al embajador del Emperador de Alemania. Asimismo, el Duque de Medinaceli —Caballerizo Mayor del Rey- ofrecio en la Corte un exquisito refresco, una cena con baile, y una "fiesta española de teatro". Gaceta de Lima, núm. 13 (4 de julio a 12 de octubre de 1764), op. cit., págs. 164-168.
} 
nistros y personas de la mayor distinción de ambos sexos, a disfrutar el magnífico exquisito refresco, la fiesta de teatro en idioma español, la cena, y bayle que estaban dispuestos, y merecieron general aplauso" ${ }^{36}$.

Este modelo de fiestas cortesanas, por obvias razones de lejanía de la persona física del monarca ${ }^{37}$, conoció determinadas adaptaciones en Hispanoamérica, donde el monarca era encarnado por la figura del virrey. No obstante, a pesar de las modificaciones y matices que implicaban las celebraciones en una corte virreinal, se cumplía el objetivo final; en efecto, a través de los actos festivos las elites criollas, las autoridades y el conjunto de los vecinos mostraban su afecto y lealtad a la Familia Real. Con todo, en Indias, el protagonismo en la organización correspondía a los cabildos municipales, quienes adoptaban las decisiones necesarias respecto a los festejos y designaban a comisarios elegidos entre los regidores para ocuparse de la supervisión de éstos ${ }^{38}$. Precisamente a los Ayuntamientos les correspondía costear una programación solemne encaminada a provocar muestras de sumisión y obediencia en los vasallos, quienes -a pesar de la gratuidad de los espectáculos - debían financiarlos con sus impuestos o con los beneficios que reportaban los bienes de propios ${ }^{39}$; de esta forma, los fuegos artificiales, luminarias, comedias y «fiestas de toros" gravaban en exceso las economías de los cabildos americanos, pero al mismo tiempo ofrecían a los vecinos la oportunidad de divertirse, relajarse y alejarse por unos días de los hábitos de conducta cotidianos. Si bien la financiación era soportada por el vecindario representado por los cabildos, la alegría y júbilo que proporcionaban los espectáculos a la po-

Gaceta de Lima, núm. 13 (4 de julio a 12 de octubre de 1764), op. cit., págs. 168-169.

Respecto a la imagen lejana que se tenía de la Monarquía Española en las colonias americanas puede verse: Minguez CORNELLES, V., Los reyes distantes. Imágenes del poder en el México Virreinal. Castelión de la Plana, Ed. Universitat Jaume I, 1995.

38. Ciertamente, la coordinación las fiestas organizadas por los cabildos americanos para celebrar los desposorios de miembros de la Familia Real se le encomendaba a comisarios designados entre los capitulares. Esta costumbre se constató en la ciudad de México en 1722 con motivo de los respectivos enlaces matrimoniales entre el Príncipe de Asturias y una Infanta de Francia y una Infanta de España y el Rey Cristianísimo: « ... en obedecimiento de las reales cédulas que a este fin nuevamente recivieron la Real Audiencia y esta Ciudad, se promulgó en vando orden de su Excelencia; y el Ayuntamiento de esta Ciudad, para sus providencias, nombró por Commisarios a Don Joseph Mogollanes y a Don Juan de la Peña, sus regidores, en las demonstraciones más festivas, que fue excitativo a fin de que los leales ánimos de los vasallos se desahogaran en ostentosas máscaras, y los gremios en paseos, con tal gallardía y número que pide su expresión relación más dilatada para poder insinuar, y lo que no se puede dezir en los concisos apuntes de este Florilegio". Gaceta de México, núm. 5 (mayo de 1722), op. cit., pág. 44

39 Las fiestas organizadas en la ciudad de Tlascala para celebrar los matrimonios concertados entre las casas reales de España y Portugal costaron 6.434 pesos y fueron financiadas con los bienes de propios y rentas del Ayuntamiento. BNE, Gaceta de México, Z 3785, núm. 18 (mayo de 1729), pág. 142. 
blación motivaba que ésta siempre tuviese ansiedad de noticias sobre nuevos acontecimientos favorables a la Monarquía Española.

De todas formas, los Ayuntamientos, tanto en España ${ }^{40}$ como en América, encontraron la colaboración de los gremios en la preparación y financiación de las fiestas reales. Este interés de las corporaciones profesionales por incluirse en los actos programados residía en la necesidad que tenían de dejar constancia de la importancia social de sus integrantes; por esta razón, los diferentes gremios entraban en competencia y rivalidad amistosa entre ellos y también con respecto a otros estamentos sociales y políticos durante los paseos solemnes y carros triunfales que se organizaban. Ciertamente, la celebración de matrimonios de la realeza proporcionaba a estas corporaciones la posibilidad de exhibir su prestigio ante el resto de la comunidad; de ello es buena muestra el que los propios relatos publicados en la prensa periódica hiciesen hincapié en el número de gremios que intervenian en los paseos y en la gallardia que manifestaban ${ }^{41}$. Desde luego, se trataba de una ocasión propicia para que pudiesen relacionarse con la elite social y política y, de esta manera, compartir el escenario público con los capitulares del Ayuntamiento, corregidor, caciques, militares y "todas las personas de distinción". Junto a todos ellos desfilaban los carros triunfales que, en ocasiones -es el caso de Oaxaca-, llegaron a estar recorriendo las calles durante dos semanas ${ }^{42}$. Especialmente expresivo de lo dicho resultó el paseo realizado en la ciudad de Tlascala en 1729 con motivo de los matrimonios concertados entre las casas reales de España y Portugal:

«... se han celebrado con todo lucimiento, dando principio con un vistoso Passeo, que se compuso de todos los casiques capitulares de aquel ayuntamiento, montados a la brida, vestidos a la moda francessa, y un carro triumphal en que iban representando a los Sereníssimos Príncipes contrayentes, quatro niños, dos hijos de casiques y dos vezinos españoles, servianle de guarnición y custodia a esta magestuosa pompa tres compañías de soldados, una de montados españoles y las dos de casiques de aquella provincia, compuesta cada una de más de cien hombres, lucida y uniformemente vestidos..." ${ }^{43}$.

El texto que se ha extractado con anterioridad vuelve a introducirnos en el lenguaje simbólico y alegórico que caracteriza a las fiestas reales; en

\footnotetext{
40 Vid. López, R.J., Ceremonia y poder a finales del Antiguo Régimen. Galicia 1700-1833, Ed. Universidad de Santiago de Compostela, 1995, págs. 88-89.

41 Gaceta de México, núm. 5 (mayo de 1722), op. cit., pág. 44

42 BNE, Gaceta de México, Z 3785, núm. 12 (noviembre de 1728), pág. 94.

43 Ibidem, Z 3785, núm. 18 (mayo de 1729), pág. 142
} 
esta ocasión, la representación escénica del carro triunfal y la composición de la comitiva que forma el paseo, entre otros mensajes, lanza la idea de integración de todos los estamentos sociales y grupos étnicos en la Monarquía Hispánica. No es casualidad, por tanto, que los príncipes contrayentes aparezcan encarnados en la persona de cuatro niños - dos hijos de caciques indígenas y dos hijos de españoles-, y tampoco que los caciques participen en la comitiva del paseo exhibiendo un comportamiento europeizado como lo demuestra el que llevasen vestidos adaptados a la moda francesa. Desde luego, con esta teatralización urbana se dejaba claro que la Corona aceptaba y acogía en su seno a toda la población americana, tanto a españoles y criollos como a indígenas.

Paseos y carros triunfales, aparte de otros mensajes simbólicos, evidenciaban la lealtad y afecto de los diferentes estamentos sociales hacia la Familia Real; no en vano, todos los integrantes de las comitivas, bajo una sola voz que contribuía a dotar de cohesión a la relación del pueblo con la Corona, daban calurosos "vivas" a los contrayentes ${ }^{44}$.

En este contexto, el pueblo llano asistía a las fiestas regias como mero espectador, excepcionalmente alguno de sus componentes se incluía en cortejos o representaciones públicas en calidad de actores secundarios; por supuesto, el protagonismo estaba reservado a las elites sociales y políticas, quienes con sus lujosos vestidos y comportamientos ostentosos trataban de causar admiración al conjunto de la población. De todas formas, la Monarquía y las autoridades indianas insistieron en propiciar la asistencia del conjunto de los vecinos a los diversos actos programados elaborando bandos y adoptando otras medidas de promoción de los festejos ${ }^{45}$. Si atendemos a la información que nos ofrecen las distintas relaciones publicadas en la prensa periódica se observa que la participación fue masiva; de tal modo es asi que con asiduidad se menciona la presencia de la totalidad del vecindario y de forasteros e indígenas venidos del entorno próximo a la ciudad, con lo que se atestigua el cariz integrador de todas las etnias que presidía estas celebraciones de los enlaces nupciales.

${ }^{44}$ El paseo organizado en Veracruz, en 1722, con el fin de celebrar el enlace conyugal del Príncipe de Asturias con la Infanta de Francia demuestra esa cohesión social en torno a los matrimonios reales: "... que fue el dia 16 se formó un lucidíssimo passeo, en que salieron el Sr. Corregidor, con sus capitulares, y todas las personas de distincción, assi políticos como militares, con galas muy costosas y libreas competentes en los lacayos, y hachas encendidas en las manos, proclamando todos en plausibles vozes: ¡Viva el Serenissimo Príncipe de Asturias y su amada consorte!". Gaceta de México, núm. 6 (junio de 1722), op. cit., pág. 57.

45 En Santiago de Compostela, entre esas medidas de promoción, se constata la utilización de medios coercitivos tales como la imposición de penas pecuniarias a los particulares e instituciones que no participasen en las fiestas regias. LOPEZ, R. J.: op. cit, pág. 224. 
Desde luego, los vítores y aclamaciones que dedicaban a la Familia Real y el adorno de las fachadas de las casas particulares se constituían en hábitos de conducta expresivos de la participación de la totalidad de la población y de la colaboración que ésta prestaba a la organización.

Las celebraciones matrimoniales en la capital de España adoptaban un modelo esencialmente elitista, en el que los "actores" de la fiesta se reducian a la Familia Real, embajadores, altos cargos de las casa reales, ministros, prelados y nuncio apostólico, nobleza, miembros de los consejos y de los tribunales, Cabildo de la Villa de Madrid y componentes del séquito que formaba parte de las comitivas reales. A todos ellos iban dirigidos la mayor parte de los actos programados - banquetes, bailes, comedias, etc.--; por supuesto, la asistencia de los cortesanos a estos actos estaba asegurada, ya que, entre otras razones, constituían una oportunidad nada desdeñable para atraer la atención del monarca y, de esta manera, tener la posibilidad de conseguir de él algún cargo o merced. Por su parte, los grupos sociales no privilegiados debían conformarse normalmente con la asistencia a los paseos de las comitivas regias y con la visualización de los fuegos artificiales, luminarias y adornos que engalanaban la ciudad. A pesar de ello, los cronistas dejaban constancia de la expectación que creaban las bodas reales al señalar que las calles y balcones por los que transcurrían los cortejos estaban llenos de «innumerable concurso del pueblo".

Con todo, los matrimonios de la realeza no impactaban exclusivamente en los sectores políticos y sociales, sino que también hallaron ciertos ecos en el ámbito intelectual. En efecto, las propias academias, fundadas en el Siglo de la llustración con el apoyo de las monarquías europeas, manifestaron la alegría que les causaba estos casamientos mediante la organización de actos en los que se procedía a dar lectura a panegíricos que alababan a las diferentes familias reales. Así se hizo en la Real Academia de la Historia de Portugal con motivo de los conciertos matrimoniales entre las casas de España y Portugal:

"(Después de efectuados los desposorios) ... y el martes tuvo junta extraordinaria la Academia Real de la Historia, en la qual el Marqués de Valenza dixo un elegante panegyrico de sus Magestades con motivo de las regias bodas del Príncipe N. Señor; y D. Francisco Xavier de Menesses, Conde de Ericeira, dixo otro sobre el assumpto de los desposorios de la Señora Princessa de España, compitiéndose uno y otro en la eloquencia" ${ }^{46}$.

BNE, Gaceta de México, Z 3785, núm. 6 (junio de 1728), págs. 47-48. 
La Corona, ante todo este afecto y culto que los súbditos le rendían, tenía sus propios mecanismos para corresponderles mediante la concesión de mercedes y privilegios. No obstante, de esta actitud generosa de la Monarquía Española se beneficiaron especialmente los grupos sociales privilegiados, ya que se aprovechaba la ocasión que ofrecía una boda de algún miembro de la Familia Real para conceder títulos de grandeza de España, exenciones de impuestos, nombramientos en la Administración del Estado y en el Ejército, designaciones para ocupar puestos en la Casa Real, etc. Por otra parte, el afecto paternal que decía sentir el Soberano por sus vasallos se materializó, entre otros gestos, con la concesión de indultos generales dentro de un espíritu que las propias reales cédulas calificaban de equidad y de justicia ${ }^{47}$. Evidentemente, estas mercedes y beneficios suponían una ratificación de la alianza que la Corona había establecido con las elites políticas y sociales; pero al mismo tiempo recompensaba la lealtad y sumisión demostrada por el conjunto de la población de todos los reinos de España y América.

4. Carlos IV concedió un indulto general con motivo de la Paz con Francia y del casamiento de las infantas María Luisa y Maria Amalia, el cual fue divulgado en España y América a través de bandos y reales cédulas. Esta iniciativa del monarca quedaba recogida en el documento remitido al Regente y oidores de la Real Audiencia de Chile el 11 de noviembre de 1796: "Por orden del Rey ha remitido al Supremo Consejo de la Guerra el señor Don Eugenio (...) dos copias rubricadas de su mano del indulto general que su Magestad se ha dignado conceder a los presos que comprehende para que disponga su cumplimiento en la forma acostumbrada como lo ha executado. La primera de las referidas copias es una real cédula de veinte y dos de diziembre de mil setecientos noventa y cinco que dice assí: sabed, que siendo mi Real ánimo extender a todo el Reino el indulto que concede para Madrid, en celebridad de los matrimonios de las serenísimas intantas Doña María Amalia y Doña Maria Luisa, mis amadas hijas, a que se agrega el ajuste de la Paz con los franceses por resolución mía, a consulta de mi Consejo de la Cámara de veinte y uno de noviembre próximo, ha venido en que este indulto se publique y sea conforme a la real cédula de diez y ocho de noviembre de mil setecientos ochenta y tres, que comprehendía el concedido entonses por mi Augusto Padre, Real Decreto de treinta y uno de octubre anterior, con motivo del nacimiento de los dos infantes gemelos, mis hijos. A su consequencia concedo indulto general a todos los presos que se allasen en las cárceles de esa Ciudad y de los otros pueblos del territorio de esta Chancillería que fueren capases de él, con la circustancia de que no hayan de ser comprehendidos en él los reos de crimen de lesa Magestad, divina o humana, de laevosias, de omicidio de sacerdote, y el que no haya sido carnal o en propia y justa defensa, los delitos de fabricar moneda falsa, de incendiario, de extracsión de cosas prohividas del Reyno, de blasfemia, de sodomia, de hurto, de cohecho y barateria, de falsedad, de resistencia a la justicia, de desafio, de lenocinio, y de mala versación de mi Real hacienda, ni las penas correcsionales que se imponen por la prudencia de los jueses para la enmienda y reforma de las costumbres.. Por otra mi cédula del dia de la fecha de ésta, estendereis el indulto general, que he tenido por vien conceder, a las personas que estén presas en las cárceles de esta ciudad y de los otros pueblos del territorio de esta Chancilleria por los motivos de celebridad que en ella se refieren y porque es mi voluntad que a los que estuvieren presos por deudas, sean pobres y no tengan de qué pagar, les alcance esta gracia..." ANCH, Fondo de la Real Audiencia, volumen 2256, folios 107-110. 


\section{OTROS ELEMENTOS Y ASPECTOS DE LA FIESTA}

De la misma forma que el engranaje organizativo del que se ha ido dando cuenta en las páginas precedentes se encontraba perfectamente regulado, también el tiempo que duraban las ceremonias y festejos se ajustaba, tanto en América como en Península Ibérica, a unas directrices impuestas por el poder político. Esta evidencia motivaba que el ritual matrimonial y los festejos celebrados en la Corte de Madrid no excedieran, como norma general, de tres días ${ }^{48}$; en ellos se incluían, por supuesto, el conjunto de los actos: recepción de embajadores, firma de capitulaciones matrimoniales, toma de dichos, desposorios y bendición nupcial, paseos de las comitivas reales, felicitaciones, banquetes, bailes, comedias, etc. No obstante, este programa estricto conoció excepciones que prolongaron el espectáculo durante una quincena; asi sucedió con la boda de la Infanta María Luisa de Borbón y del Archiduque Leopoldo, en la que la Corte y el pueblo de Madrid manifestaron con profusión la gran alegría y júbilo que causó este enlace entre la Corona Española y el linaje del Emperador de Alemania llevando a efecto un numeroso y complejo conjunto de actos en el que participaron otras casas reales europeas.

En las colonias americanas, donde la noticia de las nupcias de la realeza podía conocerse seis meses o un año después de que hubieran sido contraídas y dónde las circunstancias propiciaban que en algunas ocasiones tuvieran que celebrarse a los dos años de haberse producido el acontecimiento regio ${ }^{49}$, se constata igualmente la regulación de un tiempo mínimo de tres días para la realización de los festejos nupciales. Así lo hacía saber el Virrey de Nueva España con motivo del casamiento de Don Antonio de Borbón - hermano de Carlos IV - con la Infanta Doña María Amalia, pues mandaba que se publicase en todas las localidades de su jurisdicción la duración que debían tener los actos que se programaran para ensalzar este evento:

\footnotetext{
48 En otras bodas de la realeza europea, es el caso del casamiento del Príncipe Ferdinando de Prusia, también se detecta que las celebraciones acostumbraban a no superar los tres días. Sin embargo, el casamiento de María Amalia de Sajonia y el Rey de las Dos Sicilias que tuvo lugar por poderes en la Corte de Polonia se prolongó durante seis dias.

4G En Santiago de Chile se celebró el casamiento del Príncipe de Asturias Don Carlos y Maria Luisa de Parma en agosto de 1768, dos años después de recibir la real cédula que comunicaba esta noticia. Los festejos no se llevaron a cabo con anterioridad por diversas circunstancias coyunturales: rebelión indigena en la Frontera, expulsión de los jesuitas y ocupación de sus temporalidades y, por último, la muerte y exequias fúnebres del Presidente y Capitán General del Reino Don Antonio Guill y Gonzaga. ANCH, Fondo Claudio Gay, volumen 36, folios 136-137.
} 
"... mando se publique por bando y se remitan los exemplares necesarios a los señores intendentes a fin de que dispongan su promulgación en las demás ciudades, villas y lugares de su distrito, con el justo objeto de que en todas partes se celebren en la forma acostumbrada, reduciéndose las demostraciones de júbilo que deberán hacerse a tres días de iluminación, cortinas y repique general, acordando con los respectivos Párrocos se celebre en uno de estos dias misa solemne de gracias, que se verificará en esta capital el 30 inmediato, y en éste y los dos precedentes 28 y 29 se harán las enunciadas demostraciones con la decencia y decoro correspondientes" 50 .

Sin duda, en tierras americanas se detecta un esmero y esfuerzo de singular relieve en la preparación de las fiestas reales, lo que originaba que no desmerecieran con respecto a las que se realizaban en la Corte de Madrid y en otras ciudades españolas. En efecto, el esplendor y magnificencia que cobraban estos acontecimientos en las cortes virreinales contribuyó a que los enlaces conyugales concertados entre la Infanta de España y el Rey Cristianísimo y el del Príncipe de Asturias y la Infanta de Francia fuesen celebrados en México durante los tres días acostumbrados; sin embargo, a ellos hubo que añadir nuevos períodos de festejos, pues - como atestiguan las fuentes ${ }^{51}$ - la diversión continuó durante los tres dias de Pentecostés y desde la "Dominica de Trinidad hasta víspera de Corpus Christi». En ese ánimo de compensar la ausencia física de la Familia Real, tampoco quedaron por detrás en las expresiones de alegría y gozo otras ciudades indianas; es el caso de Oaxaca, en la que los actos que se programaron durante dos semanas incluian paseos de carros triunfales, toros, misa de acción de gracias, luminarias generales y fuegos artificiales ${ }^{52}$.

Dejando el marco temporal y adentrándonos en el espacio de la fiesta, resulta evidente que la ciudad se nos presenta como el escenario en el que plazas, calles, templos y otros edificios significativos se insertan en un fenómeno de transformación de la fisonomia urbana habitual. A ese cambio contribuyó sobremanera la decoración de los núcleos poblacionales -tanto de la metrópoli como de las colonias- con luminarias en las calles y hachas en los balcones y también con «ricas colgaduras y exquisitas tapicerías».

Precisamente, las luminarias, al tiempo que cumplian con la función de proporcionar claridad para permitir el desarrollo de la programación nocturna, mostraban - según se afirma en la prensa periódica - la lealtad y júbilo general de los vecinos ${ }^{53}$. Por ello, los cabildos municipales insta-

AGI, Gaceta de México, Gacetas 15/7, tomo Vlil, núm. 8 (31 de marzo de 1796), pág. 61 Gaceta de México, núm. 5 (mayo de 1722), op. cit., pág. 44.

BNE. Gaceta de México, Z 3785, núm. 12 (noviembre de 1728), pág. 94

Ibidem, (noviembre de 1728), pág. 90 
ban a través de bandos a cumplir la obligación de iluminar las fachadas de las casas de particulares.

Este aparato decorativo se hizo extensivo a todas las localidades de Hispanoamérica, si bien en Madrid - sede de la Corte Española- hubo cierta centralización de los adornos, tanto en el recorrido por el que pasaban las comitivas reales como en el entorno inmediato a los palacios en que se celebraban las nupcias. Aun así, todos los lugares de la Villa exhibían luminarias generales; no obstante, los fuegos artificiales estuvieron restringidos a los lugares más emblemáticos: Plazuela de la Pelota, Retiro, Plaza del Palacio, etc.

En las cortes europeas se detecta, con asiduidad, la integración de las luminarias y fuegos de artificio ${ }^{54}$ dentro del diseño propagandístico de la institución monárquica; en este sentido, no es casualidad que se combinasen los jeroglíficos de luces con fuegos de colores que representaban lemas, efigies y símbolos ${ }^{55}$. El espectáculo ofrecido en la Corte de Polonia el día 8 de mayo de 1738 durante las bodas de Carlos 111 -entonces Rey de las Dos Sicilias- y la Infanta María Amalia de Sajonia aporta información al respecto:

“... Aquella noche S.M.P. con toda su Real Familia, con los embaxadores y un crecidíssimo acompañamiento salieron por la ciudad a ver la magnífica iluminación de sus calles, que no obstante la mucha luvia fue tal que pareció no aver acabado el día, dexándose admirar tantos geroglíficos formados de las mesmas luces y tanta diversidad de explendores, que siendo cierto que empezaban desde los texados hasta un estado y medio del pavimento, puede decirse sin impropiedad que ardía toda la Corte, no desayudándolo los corazones de su Pueblo, cuyo excesivo gozo se abrasaba en mejor y más pura hoguera de regocijadas demostraciones $" 56$.

Por su parte, las cortes virreinales y los Cabildos americanos adoptaron el ornato europeo, de forma que en más de una ocasión llegaban a

\footnotetext{
54 En Lisboa las capitulaciones matrimoniales del Príncipe de Asturias y la Infanta de Portugal se celebraron, como se observa a continuación, dentro de un espacio escénico lleno de iluminación y de fuegos de artificio: «... a que se siguieron por la noche fuegos artificiales en el Terrero de Palacio, que estaba todo iluminado, como assimesmo la ciudad, y los navíos haziendo éstos triplicadas salvas acompañadas de las de toda la artillería del Castillo y fortalezas, cuyos regocijos se repitieron las dos noches immediatas». BNE, Gaceta de México, Z 3785, núm. 6 (junio de 1728), pág. 47.

55. Los fuegos artificiales lucidos con motivo del casamiento del Príncipe Ferdinando de Prusia expresan muy nítidamente lo dicho: «... se representó en el Theatro del Jardín la nueva opera intitulada el Templo de Amor cuyo expectáculo fue seguido de un magnífico fuego de artificio que se encendió al estruendo de doze cañonazos y terminó con los mismos. Fueron muy singulares las invenciones, lemmas, símbolos y efigies que se representaron con diversidad de colores en el mismo fuego". Gaceta de Lima, núm. 3 (9 a 28 de junio de 1756), op. cit., pág. 20.

56 BNE, Gaceta de México, Z 3785, núm. 130 (septiembre de 1738), pág. 1.040.
} 
superarlo mediante las acostumbradas luminarias e «invenciones de fuego", que como acreditan los testimonios recogidos con respecto a la ciudad de México ${ }^{57}$, solían tener una "variedad ingeniosa en peregrinas transformaciones'.

Los mensajes audiovisuales connaturales a las celebraciones quedaban complementados en todo el territorio del Imperio Español con los sonidos de las salvas de artillería, campanas e instrumentos musicales. El estruendo generado por los cañones y mosquetes de las compañías militares o de las embarcaciones situadas en las localidades portuarias ${ }^{58}$, junto a los repiques de campanas, avisaban a los vecinos del inicio de la fiesta; pero al mismo tiempo dotaban de solemnidad y esplendor a determinados actos programados ${ }^{59}$, tal y como sucedía con las salvas y repiques generales que se lanzaban al aire durante las misas que se oficiaban en la capital de España y en todas las poblaciones hispanoamericanas con el fin de dar gracias a Dios por los enlaces nupciales.

En este contexto, la música se constituia en un elemento insustituible en las ceremonias nupciales y festejos; no en vano, se hallaba íntimamente ligada a los bailes que se organizaban e, incluso, estaba unida a los Te Deum y salves a la Virgen que se cantaban en las misas de acción de gracias ofrecidas por la Casa Real Española en la Corte de Madrid o, en su caso, por el vecindario de las diferentes poblaciones españolas y americanas. Este ritual vinculado a la Iglesia contaba con la presencia de la Música de la Real Capilla cuando se trataba de la capital del Reino; no obstante, en Indias se observa también que después de las misas de acción de gracias "una armonía de clarines, dulzainas y teponastles» ${ }^{60} \mathrm{con}$ tribuía a agradar los oídos de los asistentes a las ceremonias litúrgicas. Por otro lado, las cortes europeas supieron aprovechar estos eventos matrimoniales para dejar constancia de su gusto por la música culta; de ahí

5. Gaceta de México, núm. 5 (mayo de 1722), op. cit, pág. 44.

58 En las poblaciones costeras las salvas de artilleria que estaban a cargo del ejército de tierra se sincronizaban con el sonido producido por los cañones de los barcos amarrados a sus puertos. Este hecho se advierte también en ciudades europeas como Lisboa, en la que las capitulaciones matrimoniales del Príncipe de Asturias - Fernando-y de la Infanta Maria Bárbara de Braganza se festejaron con "navios haziendo estas triplicadas salvas, acompañadas de las de toda la artillería del Castillo y Fortalezas". BNE, Gaceta de México, Z 3785, núm. 6 (junio de 1728), pág. 47 .

59 Los repiques de campanas se prolorigaban a lo largo de los días que duraba la programación; así ocurrió en la Corte de Madrid con motivo del casamiento del Príncipe de Asturias con la Princesa de Montpensier. Gaceta de México, núm. 3 (marzo de 1722), op. cit., pág. 29.

60 BNE, Gaceta de México, Z 3785, núm. 18 (mayo de 1729), pág. 142. 
que, con frecuencia, formase parte de la programación la asistencia a óperas ${ }^{61}$ y conciertos ${ }^{62}$.

La fiesta, al tiempo que era un medio de representación de la sociedad, cumplía la misión de evadir las energías negativas de la población siendo permisiva con las escenificaciones de una realidad transformada que, en el caso de las celebraciones de bodas reales, se podía visualizar mediante comedias y desfiles de máscaras. En este sentido, el teatro programado en la Corte Española para celebrar los enlaces nupciales pretendía principalmente ofrecer diversión, relax y risas a los asistentes; de esta forma, las comedias y loas, junto a los bailes y banquetes, se encargaban de proporcionar desenfado y alegría a unas ceremonias matrimoniales que se ajustaban, en general, a la rigidez del protocolo. Esta necesidad de ofrecer cierta informalidad y recreo a los festejos regios llevó a los organizadores del casamiento del Archiduque Leopoldo y de la Infanta María Luisa a preparar un apretado planing escénico que comprendía siete funciones distribuidas entre los dias de petición de matrimonio, firma de capitulaciones, desposorios y noches siguientes. Las diferentes funciones solian representarse en el Real Coliseo del Buen Retiro, incluyendo normalmente una loa y una comedia española ${ }^{63}$. Ese objetivo de entretenimiento que guiaba a las actuaciones de las compañías de cómicos no estaba ajeno tampoco al ambiente propagandístico que rodeaba a todo el ritual festivo; no en vano, las loas fueron utilizadas como instrumentos para ensalzar la personalidad y virtudes de los contrayentes $y$, por ende, de la Monarquia. Este modelo de teatro español se impuso en Indias, dónde las autoridades políticas mandaban representar comedias y desfiles de máscaras como medio para excitar y desahogar los leales ánimos de los vasallos ${ }^{64}$.

\footnotetext{
${ }_{61}$ Sirvan como muestra las celebraciones de las bodas de la realeza en Polonia y Prusia, en las que se incluian óperas con "magníficas y primorosas decoraciones". BNE, Gaceta de México Z 3785, núm. 130 (septiembre de 1738), pág. 1.041.

62 El matrimonio del Archiduque Leopoldo con la Infanta María Luisa de Borbón llevó al Conde de Rosemberg -embajador extraordinario del Emperador Alemán en la Corte de Madrida programar una serenata italiana para amenizar una de las noches festivas. Gaceta de Lima, núm. 13 (4 de julio a 12 de octubre de 1764), op. cit., pág. 166.

63 Si bien en la Corte de Madrid se impuso la comedia española, en otros paises europeos por ejemplo, Polonia y Prusia - se seguía la moda italiana, ya que se representaban comedias y sainetes al estilo de este país.

64 La noticia de los desposorios de los dos matrimonios de miembros de la realeza francesa y española fue festejada en la ciudad de México en 1722 con "ostentosas máscaras" dispuestas, según expresa la prensa periódica, con el fin de excitar y desahogar los leales ánimos de los vasallos. Gaceta de México, núm. 5 (mayo de 1722), op. cit., pág. 44.
} 
Asimismo, la diversión quedaba asegurada en tierras americanas con la organización de fiestas de toros, torneos ${ }^{65}$, juegos de cañas y de sortijas ${ }^{66}$ y enfrentamientos entre "moros y cristianos". Desde luego, se trata de entretenimientos llevados a Indias por los españoles, pero que incluso contaron con la aceptación de la población indígena.

La afición a la tauromaquia estaba tan generalizada en el siglo XVIII que difícilmente se encuentra una ciudad o población hispanoamericana en la que se celebrase una boda real sin que se corriesen toros. Las corridas tenían lugar durante un período de tiempo que oscilaba - según la documentación manejada - entre un día y dos semanas ${ }^{67}$; para ello se preparaba adecuadamente la plaza mayor de la localidad o en el caso que hubiesen construido plazas estables para la lidia se utilizaban éstas.

Si el enfrentamiento entre el animal y el hombre -ya fuese este último caballero o plebeyo- captó las preferencias del público en general, también resultaba evidente que los combates lúdicos entre personas gozaron del beneplácito de la población. De esta manera, torneos ${ }^{68}$, juegos de cañas ${ }^{69}$ o fiestas de moros y cristianos propiciaron principalmente el protagonismo participativo de los caballeros americanos y, por supuesto, el disfrute del común.

65 En las cortes europeas los torneos también formaban parte de las fiestas reales; en ellos participaban la nobleza y, en ocasiones, los propios monarcas. El casamiento de Carlos III -entonces Rey de las Dos Sicilias-y María Amalia de Sajonia se celebró en la Corte de Polonia "con un torneo, siendo cabo de una de las quatro quadrillas que le componían Su Magestad Polaca, y se repartieron preciosos premios entre los quadrilleros". BNE, Gaceta de México, Z 3785, núm. 130 (septiembre de 1738), pág. 1.041.

55 El juego de sortijas, de origen árabe, comenzó siendo practicado en España y América por la nobleza. Los participantes, montados a caballo, debian introducir las espadas o lanzas en las anillas de las cintas bordadas. Siempre existía una recompensa en forma de premios.

67 En la ciudad de México las fiestas de toros que tuvieron lugar con motivo de los matrimonios concertados entre las casas reales de España y Portugal duraron siete dias: “El día 8... se corrieron valientes y ferozes toros en la Plazuela del Volador, a la celebridad de los plausibles desposorios de los Serenissimos Príncipes de España y Portugal; continuaronse esta semana quatro dias, y la siguiente tres, aviéndose iluminado las tres primeras noches toda la ciudad de hachas y luminarias, en que la lealtad de los vezinos mostró su general júbilo y universal regocijo". BNE, Gaceta de México, Z 3785, núm. 12 (noviembre de 1728), pág. 90.

6e En las ciudades americanas los torneos, con frecuencia, estaban ligados a las corridas de toros; tanto es así que en la ciudad de Tlascala compartian el mismo recinto una vez que concluia la lidia taurina. Asi, al menos, lo relata la crónica publicada en la Gaceta de México en 1729: “... lidiaronse toros tres dias en la Plaza Principal de aquella ciudad, concluyéndose con un famoso torneo con que dio fin aquella noble y muy leal República a tan plausible festejo". BNE, Z 3785, núm. 18 (mayo de 1729), pág. 142.

69 El juego de cañas era muy similar a los torneos, puesto que consistía en combates en los que participaban diferentes cuadrillas de aristócratas americanos. En estos enfrentamientos demostraban sus cualidades para el manejo de los caballos, escudos y cañas. 
Todo este conjunto de festejos a los que se ha hecho referencia con anterioridad conjugaban la diversión y el mensaje propagandístico logrando atraer la atención de la totalidad de los grupos sociales españoles y americanos hacia los eventos en los que se conmemoraban los acontecimientos favorables a la Familia Real. Ciertamente, las actividades lúdicas que proporcionaban las celebraciones de los casamientos regios permitían que los súbditos liberasen sus pasiones y energías negativas; sin embargo, la aparente libertad participativa de los vasallos en estos actos se encontraba perfectamente regulada por un poder político que utilizaba a la fiesta como instrumento pedagógico al servicio de la Monarquía Española. 